\title{
Making decisions for surgical intervention in neonates with necrotizing enterocolitis and the selection of appropriate surgical intervention
}

\author{
Nekrotizan enterokolit tanılı yenidoğanlarda cerrahi girişim kararının verilmesi ve uygun \\ cerrahi girişimin seçilmesi
}

\author{
Kıvılcım KARADENIZ CERIT, Rabia ERGELEN, Tural ABDULLAYEV, Zeynep Alp UNKAR, Aslı MEMISOGLU, \\ Gürsu KIYAN, E. Tolga DAGLI
}

\begin{abstract}
Objective: Necrotizing enterocolitis (NEC) is one of the most common conditions requiring surgical intervention in the neonatal period. The decision for surgical intervention in NEC is difficult and the surgical procedures differ according to the condition of the patient. This study assesses the decision for surgical intervention in patients being followed with a preliminary diagnosis of NEC and the appropriate surgical procedure.

Material and Method: The files of patients undergoing surgery with a diagnosis of NEC at the Marmara University Hospital Neonatal Intensive Care Unit between 15.07.201315.07.2015 were studied retrospectively. Patients were evaluated for the following: gestational age, birth weight, gender, time of onset of symptoms, abdominal distention, tenderness, presence of abdominal erythema, hypotension, acidosis, thrombocytopenia, radiological findings, surgical timing and post-operative follow up.

Results: A total of 10 neonates ( 7 boys, 3 girls) were treated surgically with an NEC diagnosis. The average gestational age of the patients was 27.6 weeks (22-37 weeks), and the median birth weight was 710 grams (400-3750). Average onset of symptoms was found to be 8.1 days (2-30) postnatally. Abdominal distention and tenderness (10), hypotension (4), and abdominal erythema (3) were observed in patients upon physical examination. Acidosis (7) and thrombocytopenia (6) were observed in patients in laboratory findings. Free fluid (4), thickening of the intestinal wall ans (3), pneumatosis intestinalis (1), portal venous gas (1) were observed in patients during the assessment of the abdominal ultrasonography (US). Three patients whose direct $\mathrm{x}$-ray evaluations were grade III underwent peritoneal drainage. The drain site of one of these patients closed by itself, and there was no need for further surgery for the patient. Laparotomy was carried out a day after clinical stabilization was achieved. Our third patient, the lowest birth weight in our series, was lost immediately following the peritoneal drainage process. Peritoneal drainage was planned in
\end{abstract}

Kıvılcım Karadeniz Cerit (西), Tural Abdullayev, Gursu Kiyan, E. Tolga Dagli Sub-department of Pediatric Surgery, Department of Child Health and Pediatrics, School of Medicine, Marmara University, Pendik, Istanbul, Turkey

e-mail:kcerit@yahoo.com,kcerit@marmara.edu.tr

Rabia Ergelen

Department of Radiology, School of Medicine, Marmara University, Pendik, Istanbul, Turkey

Zeynep Alp Unkar, Asli Memisoglu

Sub-department of Neonatology, Department of Child Health and Pediatrics, School of Medicine, Marmara University, Pendik, Istanbul, Turkey

Submitted / Gönderilme: 13.07.2016 Accepted/Kabul: 27.10.2016 Was presented orally at the 33rd National Paediatric Surgery Congress, Antalya, Turkey, on 28-31 October 2015. two other grade III patients based on the radiological findings. However, due to the appearance of necrotic bowel segments from the incision site, they underwent bowel resection and ileostomy during a bedside laparotomy. One of these patients improved clinically, but the other patient was lost in the early stages. Due to the deterioration seen in the clinical findings of 5 patients who were radiologically grade II, the decision for laparotomy was made initially. All of these 5 patients were discharged after an uneventful postoperative period.

Conclusion: In patients who are grade II radiologically, the decision for surgical intervention in an operating room can be made according to clinical deterioration. In infants who are grade III, and whose clinical condition is poor, bedside surgical intervention in the neonatal intensive care unit is preferable..

Keywords: Necrotizing enterocolitis, Surgery, Laparotomy, Neonatal intensive care unit, Prematurity

\section{ÖZ}

Amaç: Nekrotizan enterokolit (NEK) neonatal dönemde en fazla cerrahi girişim gerektiren bir durumdur. Ancak cerrahi girişim kararını vermek zordur ve hastanın genel durumuna göre cerrahi prosedür değişebilmektedir. Bu çalışmada, NEK ön tanısıyla takip edilen hastalarda cerrahi girişim kararının verilmesi ve uygun cerrahi girişimin seçilmesinin değerlendirilmesi amaçlanmıştır.

Gereç ve Yöntem: Marmara Üniversitesi Hastanesi Yenidoğan Yoğun Bakım Ünitesinde, 15.07.2013-15.07.2015 tarihleri arasında NEK tanısıyla cerrahi girişim uygulanan hastaların dosyaları geriye dönük olarak incelenmiştir. Hastalar; gestasyonel haftaları, doğum kiloları, cinsiyetleri, semptomların başlama zaman1, abdominal distansiyon, hassasiyet, abdominal eritem olup olmadigi, hipotansiyon, asidoz ve trombositopeni varlığ1, radyolojik bulguları, cerrahi yaklaşım zamanı ve şekli, ameliyat sonrasi takipleri açısından değerlendirilmiştir.

Bulgular: On yenidoğana (7 erkek, 3 kız) NEK tanısıyla cerrahi girişim uygulanmıştır. Hastaların gestasyonel haftaları ortalama 27.6 hafta (22-37 hafta), doğum kiloları ortancası 710 gr (4003750 ) idi. Semptomların başlama zamanı ortalama postnatal 8.1 gün (2-30) olarak bulundu. Fizik muayene bulgularında abdominal distansiyon ve hassasiyet (10), hipotansiyon (4), abdominal eritem (3) hastada izlenmiştir.

Sonuç: Radyolojik olarak grade II olan hastalarda klinik bozulmaya göre ameliyathane şartlarında cerrahi girişim kararı verilebilir. Grade III olup, klinik olarak kötü olan infantlarda ise yenidoğan yoğun bakım ünitesinde hasta başı cerrahi girişim tercih edilebilir bir yöntemdir.

Anahtar kelimeler: Nekrotizan enterokolit, Cerrahi, Laparotomi, Yenidoğan yoğun bakım ünitesi, Prematurite 


\section{Introduction}

Necrotizing enterocolitis (NEC), is the most common and fatal condition affecting the gastrointestinal tract in the neonatal period [1]. NEC is seen at a rate of 1.1 per 1,000 live births, and this rate increases to $7 \%$ in preterms with a low birth weight between 500-1500 grams [1]. Different risk factors such as prematurity, enteral nutrition, steroids, hypotension / ischemia, indomethacin therapy for patent ductus arteriosus, and infection are associated with NEC development [2]. An increase in the prevalence of NEC has been observed in line with the development of neonatal intensive care units and an increase in survival rates of premature and low birth weight infants treated in these units [2]. The disease progresses with a wide range from light inflammation of the intestinal wall, moderate abdominal distension of the necrosis of the entire intestinal wall, respiratory and heart failure, multiple organ failure and death [3]. Detection of NEC in the early stages and making the decision for appropriate surgical timing is difficult [2].In this study, the clinical and radiological data, the decision for surgical intervention and the appropriate surgical procedure for patients followed in the neonatal intensive care unit with a preliminary diagnosis of NEC were retrospectively evaluated.

\section{Material and Method}

Patients undergoing surgery with a diagnosis of NEC at the Marmara University Hospital Neonatal Intensive Care Unit between 15.07.2013-15.07.2015 were included in this study. The patient files were examined retrospectively. Patients were evaluated for the following gestational age, birth weight, gender, time of onset of symptoms, abdominal distention, tenderness, presence of abdominal erythema, hypotension, acidosis thrombocytopenia, radiological findings (Bell classification in direct x-ray, ultrasonographic findings), surgical timing and post-operative follow up.

\section{Results}

Ten patients ( 7 boys, 3 girls) were operated on with a diagnosis of NEC between July 2013 and July 2015. The average gestational age of the patients was 27.6 weeks (2237 weeks). Median patient birth weight was 710 grams (4003.750 gram). The average time to onset of symptoms was 8.1 days (2-30 days). Abdominal distention and tenderness (10), acidosis (7), thrombocytopenia (6), hypotension (4), and abdominal erythema (3) were observed in patients (Figure 1).

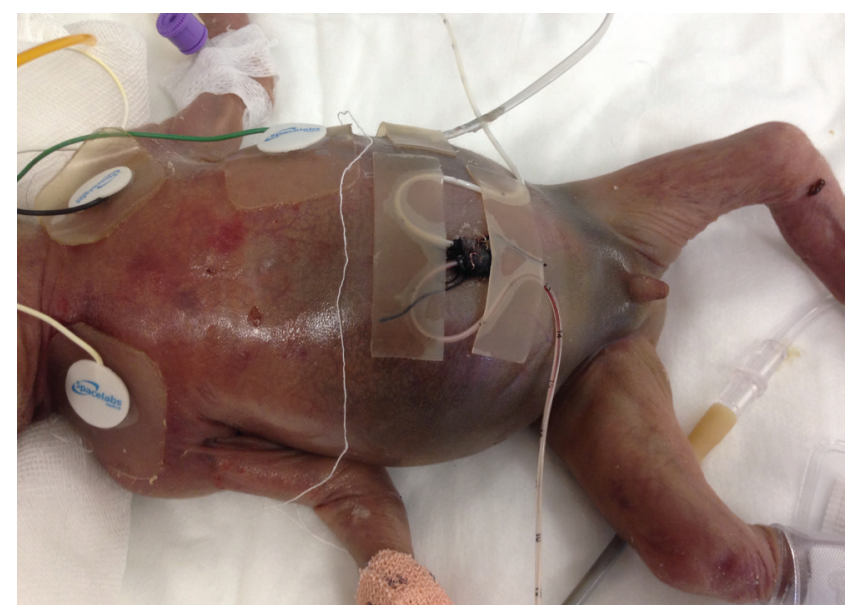

Figure 1. Abdominal distention, tenderness and erythema

Radiographs of the patients were evaluated by the same radiologist. In the evaluation of the direct $\mathrm{x}$-rays of patients according to Bell classification, 5 patients were considered Grade II, 5 patients Grade III (Figure 2). Free fluid (4), thickening of the intestinal wall ans (3), pneumatosis intestinalis (1), portal venous gas (1) were observed in patients during the assessment of the abdominal ultrasonography (US).

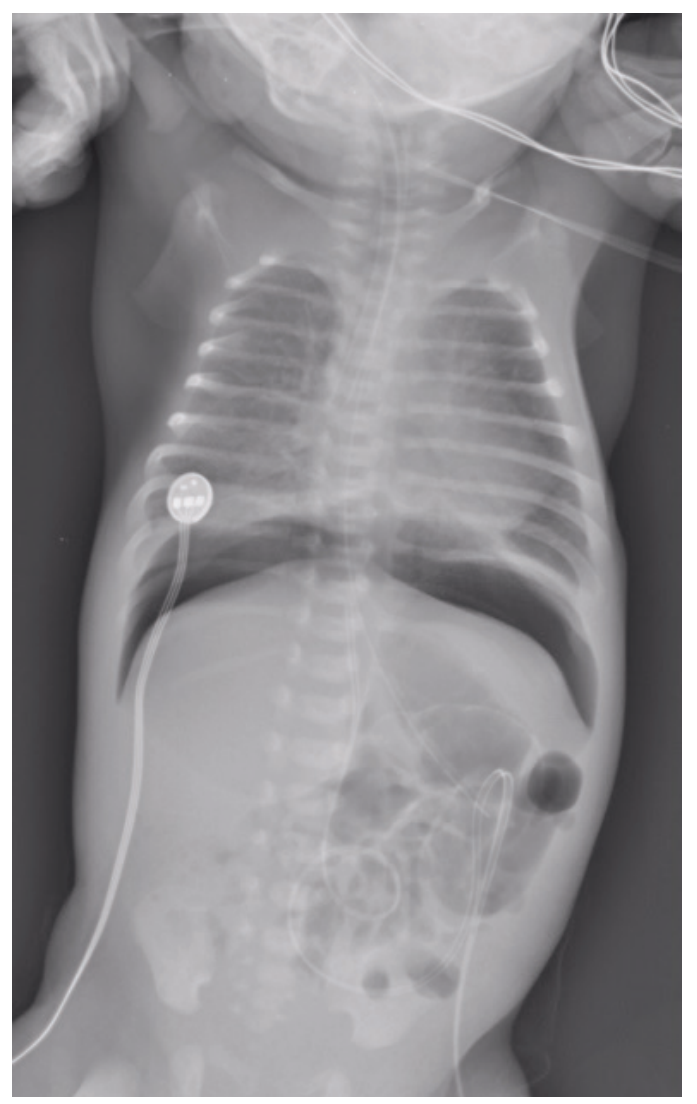

Figure 2. Free air in X-ray 
In our study, 3 patients who were considered grade III in radiological assessment were given peritoneal drainage (Table I: patients numbered 1, 3, 4). In one of these patients there was faecal discharge following peritoneal drainage. The drain site closed by itself after a week and no additional surgical intervention was required (Table I: patient no 3 ). In one patient, laparotomy was carried out in operating theatre conditions a day after clinical stabilization was achieved (Table I: patient no 4). Our third patient, the lowest birth weight in our series, was lost immediately following the peritoneal drainage process (Table I: patient no 1). Peritoneal drainage was planned in two other grade III patients radiologically. However with the appearance of necrotic bowel segments upon an attempt of peritoneal drainage from the drain site, they underwent bowel resection and ileostomy during a bedside laparotomy (Table I: patients no 2 and 5). One of the patients improved clinically, but the other patient was lost in the early stages. Due to the deterioration seen in the clinical findings of 5 patients who were radiologically grade $\mathrm{II}$, the decision for laparotomy in an operating theatre setting was made initially (Table I: patients no 6-10). All of these 5 patients were discharged after an uneventful postoperative period.

Table I. Clinical variables of NEC patients

\begin{tabular}{|c|c|c|c|c|}
\hline Patient & $\begin{array}{l}\text { Gestationalweek } \\
\text { (GW)/birth weight }\end{array}$ & Clinical signs & Radiological signs & Surgery \\
\hline 1 & $\begin{array}{l}23 \mathrm{GH} \\
23 \mathrm{GW} \\
400 \mathrm{gr}\end{array}$ & $\begin{array}{l}\text { Abdominal distention and } \\
\text { tenderness, erythema, } \\
\text { acidosis, thrombocytopenia } \\
\text { hypotension }\end{array}$ & Grade3 & Peritoneal drainage: Faecal discharge /exitus \\
\hline 2 & $\begin{array}{l}22 \mathrm{GW} \\
545 \mathrm{gr}\end{array}$ & $\begin{array}{l}\text { Abdominal distention } \\
\text { and tenderness, acidosis, } \\
\text { thrombocytopenia, hypotension }\end{array}$ & Grade3 & $\begin{array}{l}\text { Bedside laparotomy: Faecal discharge, } 10 \mathrm{~cm} \text { bowel } \\
\text { resection and ileostomy /exitus }\end{array}$ \\
\hline 3 & $\begin{array}{l}23 \mathrm{GW} \\
710 \mathrm{gr}\end{array}$ & $\begin{array}{l}\text { Abdominal distention and } \\
\text { tenderness, erythema, } \\
\text { acidosis }\end{array}$ & Grade3 & Peritoneal drainage: Faecal discharge, drain site closed itself \\
\hline 4 & $\begin{array}{l}28 \mathrm{GW} \\
850 \mathrm{gr}\end{array}$ & $\begin{array}{l}\text { Abdominal distention and } \\
\text { tenderness }\end{array}$ & Grade3 & $\begin{array}{l}\text { Peritoneal drainage: Free air discharge } \\
\text { Laparotomy: Perforation, } 10 \mathrm{~cm} \text { ileal resection and } \\
\text { ileostomy }\end{array}$ \\
\hline 5 & $\begin{array}{l}28 \mathrm{GW} \\
1115 \mathrm{gr}\end{array}$ & $\begin{array}{l}\text { Abdominal distention and } \\
\text { tenderness, thrombocytopenia, } \\
\text { acidosis }\end{array}$ & Grade3 & $\begin{array}{l}\text { Bedside laparotomy : Perforation, } 10 \mathrm{~cm} \text { ileal resection and } \\
\text { ileostomy }\end{array}$ \\
\hline 6 & $\begin{array}{l}30 \mathrm{GW} \\
630 \mathrm{gr}\end{array}$ & $\begin{array}{l}\text { Abdominal distention and } \\
\text { tenderness }\end{array}$ & Grade2 & Laparotomy: Ischemia, $7 \mathrm{~cm}$ ileal resection and ileostomy \\
\hline 7 & $\begin{array}{l}26 \mathrm{GW} \\
645 \mathrm{gr}\end{array}$ & $\begin{array}{l}\text { Abdominal distention and } \\
\text { tenderness, acidosis }\end{array}$ & Grade2 & Laparotomy: Severe inflammation in colon, ileostomy \\
\hline 8 & $\begin{array}{l}25 \mathrm{GW} \\
725 \mathrm{gr}\end{array}$ & $\begin{array}{l}\text { Abdominal distention } \\
\text { and tenderness, acidosis, } \\
\text { thrombocytopenia, hypotension }\end{array}$ & Grade2 & $\begin{array}{l}\text { Laparotomy: Perforation, } 10 \mathrm{~cm} \text { ileal resection and } \\
\text { ileostomy }\end{array}$ \\
\hline 9 & $\begin{array}{l}37 \mathrm{GW} \\
1970 \mathrm{gr}\end{array}$ & $\begin{array}{l}\text { Abdominal distention and } \\
\text { tenderness, thrombocytopenia }\end{array}$ & Grade2 & $\begin{array}{l}\text { Laparotomy: Perforation, } 15 \mathrm{~cm} \text { ileal resection and } \\
\text { ileostomy }\end{array}$ \\
\hline 10 & $\begin{array}{l}35 \mathrm{GW} \\
3750 \mathrm{gr}\end{array}$ & $\begin{array}{l}\text { Abdominal distention and } \\
\text { tenderness, erythema }\end{array}$ & Grade2 & Laparotomy: Severe inflammation in colon, ileostomy \\
\hline
\end{tabular}




\section{Discussion}

Necrotizing enterocolitis is the most frequently experienced emergencies in the neonatal period, which is associated with a significantly high degree of morbidity and mortality [4]. Detection of NEC in the early stages and making the decision for appropriate surgical timing is difficult [2]. NEC can present with non-specific symptoms such as inability to tolerate feeding in the early period, and prematurity and neonatal sepsis [2]. After preliminary symptoms of inability to tolerate feeding and abdominal distention; changes in the body temperature, lethargy, apnoea and bradycardia follow[2]. The condition, which is serious and requires surgery, covers abdominal tenderness, peritonitis, colour changes in the abdominal wall, development of a palpable abdominal mass [2].

Appropriate and correct timing of surgery in the treatment of NEC is a very controversial issue. The lack of high specificity and sensitive tests that may be used in determining those infants who would be at greatest risk for development of the disease limits the ability for early diagnosis [5]. Many researchers have studied the different angles of aetiology including indicators and immunological markers of the disease for early diagnosis and effective treatment [6]. Evenett et al. carried out a systematic review of the studies carried out on serological tests which may be useful in the diagnosis of NEC [7]. In this review, Plateletactivating factor (PAF) and intestinal fatty acid binding protein (I-FABP) were found to have specificity and sensitivity for NEC, however they specified that this must be tested in larger scoped prospective studies [7].

Direct $\mathrm{x}$-ray, is one of the cornerstones of radiological imaging of infants thought to have NEC in neonatal intensive care units, however it is relatively weak in terms of sensitivity and specificity [2,5]. In the evaluation of the direct $\mathrm{x}$-rays of patients in our study, 5 patients were considered Grade II, 5 patients Grade III. Decision for surgical intervention was made in 5 grade III patients (Table I: patients no 1-5).

In abdominal US, bowel movements, free fluid, thickening of the intestinal wall ans, pneumatosis intestinalis, pneumoperitoneum, gas in the portal vein can be evaluated [8]. Recently, necrotic bowel segment in NEC can be identified with the use of Doppler US [2,4]. In our study, in the abdominal US assessment, pathognomonic finding of pneumatosis intestinalis, and gas in the portal vein was observed in the same patient (Table I: patient no 5). Free fluid in the abdomen was observed in 4 patients, while thickening of the wall of the intestinal ans was observed in 3 patients, however these findings were non-specific and have not been effective in the diagnosis of NEC (Table I: patients numbered 1-4).

In a study by Tepas et al. it is stated that the existence of certain criteria showing irregularity in the metabolic condition of the patient is helpful in surgical decision [6]. The existence of three of seven criteria, including positive blood culture, acidosis, bandemia, thrombocytopenia, hyponatremia, hypotension and neutropenia are argued to be an indicator for surgical intervention [6]. In a retrospective study carried out by Munaco et al., they attempted to predict the requirement for surgical intervention in infants with NEC according to criteria developed according to the clinical, radiological and laboratory values, and argue that surgical intervention is required in the presence of three or more indicators [9]. In the retrospective review of the decision for surgical intervention in our study; the decision for surgical intervention was given for 5 patients who were Grade III according to the Bell classification radiologically. The method of surgery was determined according to low birth weight and general condition of the patient. (Table I: Patients numbered 1-5). In patients who were Grade II according to the Bell classification radiologically, the surgical decision was made according to increased abdominal distention and sensitivity, irregularity of metabolic condition and increased acidosis, the existence of thrombocytopenia, increased inotrope support due to hypotension, increased ventilator support (Table I: Patients numbered 6-10).

Infants with advanced NEC are generally babies with high inotrope and mechanical ventilator support needs [10]. Particularly if the operating theatres in the hospital are on another floor, significant difficulties are experienced in the transport of these patients for surgical intervention. Even if the operating theatre is on the same floor, serious clinical deterioration can occur in the transport of an intubated baby under inotrope support. In such cases, bedside surgical approach in the neonatal intensive care unit may be preferred. In our study, 2 patients were treated with bedside laparotomy. Peritoneal drainage was attempted in these patients, however with the appearance of necrotic bowel segments upon an attempt of peritoneal drainage from the drain site, they underwent bowel resection and ileostomy with bedside laparotomy (Table I: patients no 2,5). One of the patients improved clinically, but the other patient was lost in the early stages. 
Peritoneal drainage (PD) is a method first identified by Ein in order to treat low birth weight neonates with intestinal perforation but which cannot tolerate surgical stress [11]. In following studies it has been observed that following $\mathrm{PD}$, patients have shown clinical improvement without the need for surgery $[12,13]$. In our study, 3 patients were given peritoneal drainage (Table I: patients numbered 1,3,4). In one of these patients there was faecal discharge following peritoneal drainage, the drain site closed by itself after a week and no additional surgical intervention was required (Table I: patient no 3). In one patient, laparotomy was carried out in operating theatre conditions a day after clinic stabilization was achieved (Table I: patient no 4). Our third patient, the lowest birth weight in our series, was lost immediately following the peritoneal drainage process (Table I: patient no 1). In two prospective randomised studies carried out recently, the efficiency of the two methods have been compared. In the international, prospective, randomized study of very low birth weight infants with pneumoperitoneum by Rees et al., the heart rate, blood pressure, inotrope requirement and partial oxygen pressure/inspiration oxygen fraction were compared in the postoperative day 1 following PD and laparotomy [14]. In both methods, no significant difference was seen in the variables of the patients before and after the procedure [14]. Rees et al. argued that PD in the early period did not improve early survival in infants with low birth weight intestinal perforation, and that these patients require delayed surgery [14]. In a multicenter, randomized and controlled study carried out by Moss et al. perforated NEC patients treated with PD or laparotomy were assessed, with primary outcome of survival at postoperative day 90 , and secondary outcome of dependence on parenteral nutrition on the postoperative day 90 , and the period of stay in hospital [15]. According to data, in NEC patients with intestinal perforation; they argued that PD or laparotomy approach makes no significant difference in terms of mortality, dependence on parenteral nutrition, or period of stay in hospital [15]. In a review published in the Cochrane database recently, it has been determined according to the results of these two studies, that PD has no significant benefit or harm in comparison with laparotomy [16].

Wright et al. found the mortality rates of bedside surgical intervention carried out in the neonatal intensive care unit to be higher $(67 \%)$ when compared to those carried out in an operating theatre (32\%) [10]. However, Frawley et al. carries out all surgery on NEC infants under 1500 grams in the neonatal intensive care unit, and reports a mortality rate of 33\% [17]. Hall et al. report that they routinely intubate, ventilate and operate on all neonates in the neonatal intensive care unit [18]. In our study, three patients were given peritoneal drainage, and 2 patients underwent laparotomy under bedside conditions. These patients were infants whose general condition was bad, with very low birth weight, receiving inotrope and mechanical ventilation support. Bedside surgical intervention in the neonatal intensive care unit is highly advantageous in terms of prevention of complications to occur during the transport of the patient. We recommend sufficient infrastructure for bedside surgical intervention in the neonatal intensive care unit.

As a result, the incidence of NEC cases increases with the development of new neonatal intensive care units. The decision to perform surgery on these patients is difficult. Close clinical observation and radiological imaging of the patients is important in the surgical decision. In patients who are Grade II, the surgical decision can be made according to increased abdominal distention and sensitivity, irregularity of metabolic condition and increased acidosis, the existence of thrombocytopenia, increased inotrope support due to hypotension, increased ventilator support. In infants who are Grade III, and whose clinical condition is poor, bedside surgical intervention in the neonatal intensive care unit is a preferable method. In very low birth weight infants whose general condition is too poor to tolerate transport to the operating theatre, we recommend the peritoneal drainage method, despite controversy, as a preliminary surgical intervention option in order to stabilize the condition of the patient prior to laparotomy.

\section{References}

1. Lim JC, Golden JM, Ford HR. Pathogenesis of neonatal necrotizing enterocolitis. Pediatr Surg Int 2015; 31: 509-18. doi: 10.1007/s00383-015-3697-9

2. Raval MV, Moss RL. Current concepts in the surgical approach to necrotizing enterocolitis. Pathophysiology 2014; 21: 105-10. doi: 10.1016/j.pathophys.2013.11.017

3. Hall NJ, Eaton S, Pierro A. Necrotizing enterocolitis: Prevention, treatment, and outcome. J Pediatr Surg 2013;48: 2359-67. doi: 10.1016/jpedsurg.2013.08.006

4. Raval MV, Hall NJ, Pierro A, Moss RL. Evidencebased prevention and surgical treatment of necrotizing enterocolitis-A review of randomized controlled trials. Semin Pediatr Surg 2013; 22: 117-21. doi: 10.1053/j. sempedsurg.2013.01.009

5. Kim JH. Necrotizing enterocolitis: The road to zero. Semin Fetal Neonatal Med 2014; 19: 39-44. doi: 10.106/j. siny.2013.10.001 
6. Tepas III JJ, Sharma R, Leaphart CL, Celso BG, Pieper P, Esquiva-Lee V. Timing of surgical intervention in necrotizing enterocolitis can be determined by trajectory of metabolic derangement. J Pediatr Surg 2010; 45: 310-4. doi: 10.106/j. pedsurg.2009.10.069

7. Evennett N, Alexander N, Petrov M, Pierro A, Eaton S. A systematic review of serologic tests in the diagnosis of necrotizing enterocolitis. J Pediatr Surg 2009; 44: 2192-201. doi: 10.1016/j.pedsurg.2009.07.028

8. Staryszak J, Stopa J, Kucharska-Miasik I, Osuchowska M, Guz W, Btaz W. Usefulness of ultrasound examinations in the diagnostics of necrotizing enterocolitis. Pol J Radiol 2015; 80: 1-9. doi: 10.12659/PJR.890539

9. Munaco AJ, Veenstra MA, Brownie E, Danielson LA, Nagappala KB, Klein MD. Timing of optimal surgical intervention for neonates with necrotizing enterocolitis. Am Surg 2015; 81: 438-43.

10. Wright NJ, Thyoka M, Kiely EM, et al. The outcome of critically ill neonates undergoing laparotomy for necrotizing enterocolitis in the neonatal intensive care unit: a 10 year review. J Pediatr Surg 2014; 49: 1210-4. doi: 10.1016/j. pedsurg.2014.01.052

11. Ein SH, Marshall DG, Girvan D. Peritoneal drainage under local anesthesia for perforations from necrotizing enterocolitis. J Pediatr Surg 1977; 12:963-7. doi: 10.1016/0022-3468(77)90607-8

12. Lessin MS, Luks FI, Wesselhoeft Jr CW, Gilchrist BF, Iannitti D, DeLuca FG. Peritoneal drainage as definitive treatment for intestinal perforation in infants with extremely low birth weight $(<750$ g). J Pediatr Surg 1998; 33:370-2. doi: 10.1016/SOO22-3468(98)90465-1

13. Rovin JD, Rodgers BM, Burns RC, Mcgahren ED. The role of peritoneal drainage for intestinal perforation in infants with or without necrotizing enterocolitis. J Pediatr Surg 1999; 34: 143-7. doi: 10.1016/S00223468(99)90245-2

14. Rees CM, Eaton S, Khoo AK, Kiely EM, Members of the NET Trial Group, Pierro A. Peritoneal drainage does not stabilize extremely low birth weight infants with perforated bowel: data from the NET trial. J Pediatr Surg 2010; 45:3249. doi: 10.1016/j.pedsurg.2009.10.066

15. Moss RL, Dimmit RA, Barnhart DC, et al. Laparotomy versus peritoneal drainage for necrotizing enterocolitis and perforation. N Engl J Med 2006; 354: 2225-34.

16. Rao SC, Basani L, Simmer K, Samnahakay N, Deshpande G. Peritoneal drainage versus laparotomy as initial surgical treatment for perforated necrotizing enterocolitis or spontaneous intestinal perforation in preterm low birth weight infants. Cochrane Database Syst Rev 2011; 15; 6: CD006182. doi: 10.1002/14651858.CD006182.pub2

17. Frawley G, Bayley G, Chondros P. Laparotomy for necrotizing enterocolitis: intensive care nursery compared with operating theatre. J Paediatr Child Health 1999; 35: 291-5. doi: 10.1046/j.1440-1754.1999.00364.x

18. Hall NJ, Stanton MP, Kitteringham LJ, et al. Scope and feasibility of operating on the neonatal intensive care unit: 312 cases in 10 years. Pediatr Surg Int 2012; 28:1001-5. doi: 10.1007/s00383-012-3161-z 